4. The best use of bibliographical and other records in maintaining and improving library and information services in the legal field.

5. New forms and channels of regular communication between the $\mathrm{BL}$ on the one hand and law libraries and users of legal literature and information on the other.

Comments, enquiries and submissions will be welcomed by the Secretary, Miss Mary Goldrick, The British Library, Official Publications Library, Great Russell Street, London WC1B 3DG (Telephone 01-6361544 ext. 234). These should be sent by March 1982 at the latest.

\title{
FELLOWSHIPS FOR FOREIGN LAW LIBRARIANS IN THE UNITED STATES
}

The Charles A. Dana Foundation in the United States, which made a generous grant to the IALL in 1978 for the purpose of holding its highly successful first Latin American Conference in Quito, Ecuador, has further extended its support for the advancement of international law librarianship through the creation of a Fellowship for Foreign Law Librarians.

The first recipients of the Fellowship in 1981 were Ms. Vivian Fletcher, Assistant Librarian at the Law Library of King's College, the University of London, and Ms. Rasri Thepuichien, the librarian for the International Legal Counsellors Thailand Ltd. in Bangkok, Thailand.

Each participant spent this summer studying law library operations in Southern California where their sponsors were the California Western School of Law Library, the San Diego County Law Library, and the Library of the California State Attorney General.

\section{CENTRAL AMERICAN COMMON MARKET BIBLIOGRAPHY}

Ellen Schaffer, Reference Librarian at the Columbus Memorial Library of the Organization of American States in Washington, has compiled an interesting 10-page bibliography of books and articles on the Central American Common Market covering the period from 1975 through 1980. The bibliography has been issued by the OAS General Secretariat as item No. 4 in its Documentation and Information Series (Document No. OEA/SG/0.1/IV/III.4).

The Central American Common Market came into existence in 1960 pursuant to the Central American Integration Treaty. That treaty expired in June, 1981, and there are plans in existence for negotiations leading to the establishment of a new regional economic arrangement in 
Central America. The bibliography offers useful hints about relevant background reading materials for such negotiations. The future of economic integration or cooperation in Central America is of course dependent on the emergence of regional political stability.

\section{INFORMATICS LAW}

A commission has been established by the Intergovernmental Bureau for Informatics (located at 23, viale Civilta del Lavoro, 00144 Rome, Italy) to study the application of computer and other technology to legal information research (named by the Bureau as "informatics law" which is based on the French word "informatique") and the regulation by law of information data production and use.

The commission has recently issued a report on the Considerations for the Study of Informatics Law (Intergovernmental Bureau for Informatics Documents on Informatics Law, Orange Series, DR. 01) which contains the outline of an ambitious international program for cooperation in the development of retrieval technologies for legal information, as well as recommendations for a suitable international legal regime dealing with the distribution of information. Discussion of these issues will be given a prominent place in the program of the $2 \mathrm{~d}$ Intergovernmental Conferences on Informatics Strategies and Policies, organized by the Intergovernmental Bureau for Informatics for mid-1983.

\section{NEW COMPANIES LEGISLATION IN AUSTRALIA}

On 18 June 1981 the Companies Act 1981 (no. 89 of 1981) was assented to by the Australian Parliament. (Available from A.G.P.S., Canberra, A.C.T., Australia, 2600. Cat. no. 81 41174. Price: A\$ 15.20). The Act is expected to come into operation early in 1982. Nine Acts associated with the new national companies and securities legislation also received assent on 18 June 1981. New regulations under these Acts have also been made.

The best advice one can give to the foreign law librarian, who has an interest in Australian companies and securities law is to suggest that he/she subscribe to $\mathrm{CCH}$ Australia Limited's Australian Company Law and Practice. This new service will replace the $\mathrm{CCH}$ Australian Corporate Affairs Reporter by early 1982. The first volume of the ACLP is already available and contains the full text of all the relevant Acts together with practical commentary. The second loose-leaf volume is expected to be issued in December 1981 containing detailed explanations of the new legislation. 